\title{
THE ISLAMIC FORMALISM MOVEMENT IN MALAY LAND: EXPERIENCES OF THE MUSLIM COMMUNITY IN KERINCI, JAMBI
}

\author{
Marjan Fadil \\ Institut Agama Islam Negeri (IAIN) Kerinci, marjanfadil@gmail.com \\ Martunus Rahim \\ Institut Agama Islam Negeri (IAIN) Kerinci, martunusrabim@gmail.com \\ Indra Ikhsan \\ Institut Agama Islam Negeri (IAIN) Kerinci, indradetroit@gmail.com \\ (C)2021 by the authors. Submitted for possible open access publication under the terms and conditions \\ of the Creative Commons Attribution-ShareAlike 4.0 International License (CC-BY-SA) \\ license (https://creativecommons.org/licenses/by-sa/4.0/) \\ do) DOI: http://dx.doi.org/10.30983/fuaduna.v5i1.4596
}

Submission: 30 March 2021
Revised: 20 June 2021
Published: 30 June 2021

\begin{abstract}
This article aims to analyze the development of Islamic religious movements in the Malay traditional land of Kerinci Jambi, particularly related to the tendency of religious formalism in Islamic communities. The pattern of education, local customs and traditions, as well as religious ideology contributed to the emergence of a Muslim community that only paid attention to the formal side of religion or known as formalist Islam. This study uses an anthropological approach through interviews, observations, and documentation of Muslim communities in Kerinci Jambi. This paper finds that formalist Islam tends to be difficult to develop in Malay society exclusively from indigenous groups, and more easily accepted for inclusive societies from immigrant groups or mixing with outsiders and academics. This exclusive Malay community seeks to maintain the Islamic ideology that has been institutionalized in the structure of society that does not contradict between custom and religion since the first, namely Islam with the nuances of Sufism, based on the Shafi'i Madhhab in figh, and al-Ghazali Madhhab in theology. Meanwhile, inclusive societies tend to be open to accepting various Islamic identities and most of them do not hold strong traditional values.
\end{abstract}

Keywords: Islamic Formalism; Muslim Community; Malay World.

\section{Abstrak}

Artikel ini bertujuan untuk menganalisis perkembangan gerakan keagamaan Islam di tanah adat Melayu Kerinci Jambi, khususnya terkait kecenderungan formalisme keberagamaan komunitas-komunitas Islam. Pola pendidikan, adat dan tradisi lokal, serta ideologi keagamaan memberi kontribusi bagi kemunculan komunitas Muslim yang hanya memperbatikan sisi formal agama saja atau dikenal dengan Islam formalis. Studi ini menggunakan pendekatan antropologis melalui wawancara, observasi dan dokumentasi terhadap komunitas-komunitas Muslim yang terdapat di Kerinci Jambi. Tulisan ini menemukan bahwa Islam formalis cenderung sulit berkembang dalam masyarakat Melayu eksklusif dari golongan masyarakat pribumi, dan lebih mudah diterima bagi masyarakat inklusif dari golongan pendatang atau percampuran dengan masyarakat luar dan para akademisi. Masyarakat Melayu eksk.lusif ini berupaya mempertahankan ideologi Islam yang telah melembaga dalam struktur masyarakat yang tidak mempertentangkan antara adat dan agama semenjak dabulu yakni Islam dengan nuansa tasawnf, bermazhab Syafi'i dalam fikih, dan bermazhab al-Ghazali dalam teologi. Sedangkan masyarakat inklusif cenderung terbuka menerima beragam identitas Islam dan mereka sebagian besar tidak memegang nilai adat secara kuat.

Kata Kunci: Formalisme Islam; Komunitas Muslim; Dunia Melayu. 


\section{INTRODUCTION}

Islamic formalism is also known as the formalization of Islamic law, which begins at the ideological level and then manifests in a social context. The problem of the formalization of sharia in Indonesia must be understood in terms of ideology and social reality in which these community groups live which form differences in efforts to formalize sharia. ${ }^{1}$

Formal means are synonymous with symbols indicating an Islamic group that attaches importance to symbols and wants Islam to be uniform in every line of society. M. Syafii Anwar explained that Islamic formalism is the institutionalization of religious doctrines, symbols, and ideologies. Meanwhile, formalistic means the orientation of the realization of an Islamic political society, such as the formation of an Islamic political system, Islamic culture, and Islamic state administration, so that formalist groups tend to emphasize political-ideological embodied in formal religious symbols. ${ }^{2}$

The research on the development of the formalization of Islam, as said by Irfan Noor, was influenced by Transnational Islamic Groups in a global context such as Hizbut Tahrir, the Indonesian Mujahideen Council, the Salafi Movement, and other movements that have metamorphosed and developed in more than 22 districts and cities throughout Indonesia. ${ }^{3}$ Formalist Islam cannot be equated with radical Islamic groups as written by Ubaidillah Achmad, ${ }^{4}$ because there are quite a lot of Islamic movements that have formal or legal views but are not manifested in the form of violence.

\footnotetext{
${ }^{1}$ Mahmuddin, "Formalisme Agama Dalam Perspektif Gerakan Sosial: Prospek Dan Tantangan Di Masa Depan," Jurnal Diskursus Islam 3, no. 1 (2015): 37-48.

2 M. Syafii Anwar, Pemikiran Dan Aksi Islam Di Indonesia (Jakarta: Paramadina, 1995), 146.

3 Irfan Noor, "Sufisme Seyyed Hossein Nasr Dan Formalisme Agama Di Indonesia," $A L-B A N J A R I 13$, no. 2 (2014): 143-264.
}

Islamic movements that have emerged in society have actually become interesting material for the general public to decide what kind of Islam is. People who do not really understand Islam, unwittingly close the possibility of developing diversity in Islam. The question is, isn't that different a fitrah in Islam? Quraish Shihab explained that why the difference is not a disaster, because the difference has appeared in the history of Islam. This is illustrated for example from the Hanafi Madhhab which is attributed to Imam Abu Hanifa (d. 767M). The main characteristic of this madhhab is that it answers many assumptions about fiqh problems that will occur in the future (al-figh al-iftiradhi), or the Maliki Madhhab by Imam Malik bin Anas (719-795 AD) with the main characteristic of the practice of the people of Medina sometimes being higher, from the hadith of the Prophet Muhammad. The Shafi'i Madhhab, which is attributed to Imam Muhammad bin Idris As-Syafi'i (767-820 AD), is actually very strict in using the Sunnah of the Prophet. There is also the Hanbali Madhhab by Muhammad bin Hanbal (780-855 AD) with their main characteristics being understood the text literally, they only believe in the practice of the early period of society (salaf alsalib). ${ }^{5}$ In fact, there are many other groups such as the Zaidiyah Madhhab, Zahiriyah Madhhab, and others. Of the various madhhab of thought, there are eight madhhabz of which have been agreed upon by scholars in the world and are considered part of the Muslim group.

In the context of religion in Indonesia, religious movements are at least divided into several patterns of movement. As written by Azyumardi Azra that the articulation of religious

\footnotetext{
${ }^{4}$ Ubaidillah Achmad, "Islam Formalis Versus Islam Lokalis: Studi Pribumisasi Islam Walisongo Dan Kiai Ciganjur," ADDIN 10, no. 1 (2016): 233-62.

${ }^{5}$ M. Quraish Shihab, Islam Yang Saya Anut DasarDasar Ajaran Islam (Tangerang: Lentera Hati, 2018), 13-15.
} 
movements is at least illustrated by three typologies, such as substantialism, legalism/formalism, and spiritualism. ${ }^{6}$ In simple terms, it can be described as follows: first, substantialism is a religious understanding that is more concerned with substance than religious symbols. This understanding tends to look at the implicit teachings of Islam. The second is formalism/legalism, namely the Muslim community which emphasizes formal rules and religious law. This group in society can be seen as those who express religious symbols and must be manifested explicitly in all areas of life. This view can also be seen from those who try to wear Arabstyle clothing. The third spiritualism is an understanding that places more emphasis on spiritual development that is spiritual in nature. This understanding tends to be exclusive, by connecting with their group in an effort to get closer to Allah SWT. This group rarely appears on the surface of society, although its appearance is sometimes often expressed as different Islamic teaching from the teachings of Islam that usually develop in Muslim society in general.

The theory of formalism actually develops in the literary tradition wherein understanding meaning, revolves around the formal side and dimensions of language. ${ }^{7}$ However, in the context of social movements, this is illustrated by people who tend to understand religion from the formal side and manifest these formalities in religious life in the form of symbols used, such as clothes, flags, attitudes, and so on. Although this grouping cannot be used as a permanent reference in the category of society.

6 Azyumardi Azra, Konteks Berteologi Di Indonesia: Pengalaman Islam (Jakarta Selatan: Paramadina, 1999), 8-9.

${ }^{7}$ Fredric V. Bogel, New Formalist Criticism (New York: Palgrave Macmillan, 2013), 3.

${ }^{8}$ Cliffort Geertz introduced the categorization of the social class of Muslims in Java with the first Abangan, namely the Islamic community who understand Islam loosely and believe in superstition; Second, Santri, namely people with Islamic educational backgrounds and rejecting superstitious
There is no strong evidence yet about when Islamic formalism emerged in Kerinci. Broadly speaking, the understanding of formalism has been formed and developed in the Kerinci community around the 90s, beginning with the entry of Muhammadiyah and Nahdlatul Ulama (NU) to Kerinci. The ideology of formalism in Kerinci is widely seen in various campuses such as the State Islamic Institute (IAIN) Kerinci, STIE (Academy of Economics), STKIP (Academy of Teacher Training and Education), AMIK-DP (Academy of Informatics and Computer Management-Depati Parbo), and several other campuses. From several campuses, adherents of formalism can be seen from the students of IAIN.

In general, adherents of formalism from the community in Kerinci Regency, do not fully have a strong desire to uphold the chalipate, but in principle, they fully support it so that the chalipate can be enforced in every line of community life. With the various tribes in it, such as the Kerinci, Minang, Javanese, Batak, and Chinese, it is interesting how formalist Islam is able to adapt well in the community. The understanding of Muslims that is widely embraced by groups as described above is often referred to as Salafi teachings. As Van Bruinessen wrote, Salafism is the main attraction for people with abangan background ${ }^{8}$, because the existing rules are simple and have clear rules. This transnational character is the main attraction for a cosmopolitan society. ${ }^{9}$

The expansion of the Salafism movement was illustrated in the mid-1980s in Indonesia, with the characteristics of a long beard (libya), Arab-style robe (jalabiyya), turban (imama), and wearing

teachings; Third, the Priyayi group is a respectable Muslim community who is not too obedient to the teachings of Islam.

${ }^{9}$ Bruinessen M. Van, "Introduction: Contemporary Developments in Indonesian Islam and the "Conservative Turn' of the Early Twenty-First Century," in Contemporary Developments in Indonesian Islam: Explaining The "Conservative Turn” (Singapura: Institute of Southeast Asian Studies, 2013), 15. 
trousers above the ankles (isbal). For the failure of Islamization by an Islamic political movement that claims to be true Islam. ${ }^{10}$

This view of formalism in the context of politics is illustrated from the verse "... So decide their case according to what Allah has sent down and do not follow their desires by leaving the truth that has come to you ..." (Q.S. Al-Maidah: 48). This verse is understood as the main demand so that Muslims submit to the rules that already exist in Islam, because Islam has taught everything related to life in the world. This is also reinforced by the surah Q.S. Al-Baqarah: 208 which teaches Muslims to live Islam in kaffah (totality). The role of reason in religion is often regarded as a fatal error and a sin. Furthermore, some are even struggling to replace the current system of government in Indonesia with the caliphate system as in the past. Their basis regarding this is illustrated in the verse "Indeed I want to make on earth a caliph." (Q.S. Al-Baqarah: 30). The understanding of the meaning of khalifah (caliph) in this verse is understood as kbilafah (caliphate). ${ }^{11}$ This means that there is only one leader (khalifah) that God wants. Through the data above, it seems necessary to study further how the understanding of formalism groups adapts to the current situation, especially for some groups such as Hizbut Tahrir Indonesia (HTI). Because as explained earlier, this group takes various forms, from relatively gentle to strict in Islam.

This study uses an anthropological approach through interviews, observations, and documentation of Muslim communities in Kerinci Jambi. Field research was carried out in the period 2020-2021.

10 Noorhaidi Hasan, "The Salafi Movement in Indonesia: Transnational Dynamics and Local Development," Comparative Studies of South Asia, Africa and the Middle East 27 (January 2007): 83-94, https://doi.org/10.1215/1089201x-2006-045.

\section{THE KERINCI COMMUNITY IN TRADITION AND RELIGION}

The naming of the city of Kerinci, in history, is illustrated by the geographical contours and the environment that surrounds it, which is divided into several versions. First, the opinion that says that Kerinci is symbolized by its nature which is surrounded by hills or the term secret valley ${ }^{12}$, and in it lives a variety of wild animals and plants, and is difficult to access. Therefore, Kerinci was then considered a "locked" area from other areas. So the term Kerinci is considered to come from the word "key" or also "locked" which later became Kerinci. In general, Minang people refer to Kerinci as "Kurinci". Second, historically the Kerinci area is divided into 2 parts, namely the lower part of the land and tends to be wet (cair), then the second part is the drier (kering) area and is in the highlands, so the term kering-cair (dry-liquid) which was eventually adopted in the local language as kehing or khing and liquid or caye. When these two words are combined, it will sound khingcaye and change to Kerinci's name, namely "Kincai". Third, the opinion that the arrival of Melanesian tribes from mainland Asia through the Malacca Peninsula then crossed the Malacca Strait and along the east coast from Sumatra Island and arrived at the Berhala Strait. This tribe then turned to the Batang Merangin area, until it reached its upper reaches, which is near Lake Kerinci today. They then saw that many people who live in the Kerinci area are still primitive and many of them live in caves. So then the newcomers call the area they meet Kerinci which means upstream of the river, and the people who inhabit the area as Kerinci people which means upstream of the river.

Geographically, Kerinci is a strategic area in Jambi Province, so it is called Kerinci Regency. The use of the name Kerinci is not only for the area

11 Fakhruddin (Former Head of HTI Branch Kerinci), Interview, 2018

12 C. W. Watson, Kerinci: Two Historical Studies (Canterbury: University of Kent, 1984), i. 
but also for the people, which are called the Kerinci tribal community followed by various natural phenomena named Kerinci, such as Kerinci Lake, Mount Kerinci and so on.

According to data that written by the Central Bureau of Statistics (BPS), Kerinci Regency is geographically located between 1o 40' South Latitude to 2o 26' South Latitude and between $101 \mathrm{o}$ 08' East Longitude to 101o 50' East Longitude. It is bordered to the north and west by West Sumatra Province. To the south, it is bordered by Bengkulu Province and in the east by Merangin and Bungo Regencies. The area of Kerinci Regency is $3,449.31 \mathrm{Km} 2$ or $6.64 \%$ of the total area of Jambi Province. Of this area, 59.82\% is the area of the Kerinci Seblat National Park (TNKS) and $40.18 \%$ is the area for cultivation and residential areas. ${ }^{13}$

The administrative area of the Kerinci Government is bordered by the Solok Regency in West Sumatra Province to the north, and from the south by Merangin Regency. In the east, it is bordered by Muara Bungo Regency and from the west by North Bengkulu Regency or the South Coastal area (West Sumatra). Kerinci consists of 18 sub-districts and then 2 new sub-districts were added after regional expansion, namely the West Lake Kerinci sub-district and the Tanah Cogok sub-district. The following is the percentage of the area in Kerinci Regency in 2020 which is taken from BPS data. ${ }^{14}$

An article by Van Aken and quoted in the book Adat Basandi Syara: Sebagai Fondasi Membangun Masyarakat Kerinci, explains that from 1960 to 1970 the increase in the population of Kerinci was only 1.82 percent from 155,874 people in 1970 . While in the period $1970-1980$ it increased by 2.88 percent to 186,615 people and in the period 1980 1990 increased by 1.59 percent to 240,917 people. ${ }^{15}$ The low rate of population growth is influenced by

13 BPS Kabupaten Kerinci, Statistik Daerah Kabupaten Kerinci 2020 (Kerinci: BPS Kabupaten Kerinci, 2020), 1.

${ }^{14}$ BPS Kabupaten Kerinci, 2. population migration, in addition to the success of the Family Planning program. This population migration is mainly found in areas such as Rimbo Bujang, Sungai Bahar, Muara Bulian, and many others.

History records that in the early periods of Dutch colonialism (1903-1921) there, the Kerinci area was part of Jambi Recidency area. In 1921 this area was included in the afdeeling Painan under the residency of West Sumatra. During the Japanese colonial period (1942-1945), there was also a change in the status of Kerinci and Indrapura, which were combined into one area known as the Bungsyoo area, which was still under the residency of West Sumatra. After Indonesia's independence (1945), Kerinci and Pesisir Selatan were merged into one area, with Sungai Penuh as the regional capital. The next phase in 1958 through Law no. 81 of 1958 explains the inclusion of Kerinci in the formation of Jambi Province/Region level 1, then in Law no. 61 in 1958, Kerinci was also inaugurated as a Level II Regency/Region of Kerinci.

The majority of the Kerinci people are Muslims who have always lived in a unitary area of customary law, under the leadership of the Depati. At the end of the 19th century, Kerinci covered the Kerinci Tinggi and Kerinci Rendah areas. Until 1901 the Dutch began to enter the Kerinci area and met resistance from the Kerinci community until 1903. The success of the Dutch in controlling Kerinci was followed by the divide et impera policy, by dividing the Kerinci area into two parts, namely Kerinci Tinggi into Lanchap Korintii which was united with the Gouvernement of Sumatra's Weskunt (West Sumatra) and Kerinci Rendah became Onderafdeling Bangko, which was incorporated into Residentie Palembang. In 1906 Korintji entered the Jambi Residentie. At that time the Depati Empat Alam Kerinci and the Sultan of Jambi were dismissed from their positions. The

15 "Mendeeling Encyclopedisch Burean Aflevering," in Note Betreffende de Afdeeling Korintji, 1915. 
Dutch government then changed Korintii into two districts, namely Korintji Hoeloe and Korintji Hilir District and the capital city of Kerinci was in Sanggaran Agung, then in 1910 the Dutch moved it to Sungai Penuh. ${ }^{16}$

The existence of the Kerinci community is estimated to have existed since 3000-2000 BC, although it cannot be proven with certainty. One thing that is known about Kerinci is that in the early phase of Kerinci, Proto-Malays (Old Malays) from Southeast Asia (Hindia Belakang), then in 1500-1000 BC came another wave of visitors called Deutero Melayu (Young Malays). They are called the mother of the Kerinci tribe. Prehistoric evidence of the identity of the Kerinci people is mostly found in tools from the Neolithic and Bronze Ages, while artifacts from the Paleolithic period are not found. These tools include axes, pickaxes, discs, pickaxes, mortars made of stone. ${ }^{17}$

The process of entering Islam in the midst of the Kerinci community is faced with customary rules that have been institutionalized in the community for a long time. However, Islam was able to adapt well to the Kerinci customs and developed slowly, and was accepted by the Kerinci people. The suspicion is heavy that what causes Islam to be easily accepted by the people of Kerinci, because the Islam that is taught carries the influence of Sufism and does not have much confrontation with the customary system that applies to the community. The community continues to follow customary rules while understanding the values brought by Islamic teachings. Over time, there was a process of acculturation and assimilation between the two values, and the Kerinci customs were transformed into Islamic values. Therefore, when the government was ruled by the Depati Empat

${ }^{16}$ Yunasril Ali dkk, Adat Basendi Syara': Sebagai Fondasi Membangun Masyarakat Madani Di Kerinci (Kerinci: STAIN Kernci Press, 2005), 11-15.
Delapan Helai Kain, the Islamic tradition had been integrated into the Kerinci custom.

How, when and from where the process of the entry of Islam in Kerinci still does not show strong evidence. However, some descriptions can be known through the theories put forward by historians. The assumption that Islam entered Kerinci through the West Sumatra route is a very possible theory to explain when Islam entered Kerinci. This can be proven by the current culture of the Kerinci people who use symbols and customs similar to the people of West Sumatra. In addition, there are also geographical factors between Kerinci and West Sumatra which are relatively close together. Nurdin Yakub asserts that Shia and Sufism have been seen since about the time of the Dhamasraya kingdom, and spread in the East Minangkabau area in the period 11001350 AD. ${ }^{18}$

Around the 15th century AD, during the reign of Datuk Paduka Berhala and his consort Putri Pinang Masak, a relationship was established between Kerinci and Jambi. At this time Islam in these two areas already existed, under the leadership of the Depati Empat Delapan Helai Kain, which was a joint government of the Depati. At that time the government in each region had been running based on Islamic teachings, known today as the Adat Basandi Syara', Syara' Basandi Kitabullah. Syara' Mengato Adat Mamakai. At that time Islam was integrated into the Kerinci custom.

History also proves that Islam entered the land of Kerinci peacefully. The process of acculturation and assimilation between Islam and Kerinci culture took place in harmony and went well in every aspect of people's lives. According to Zufran as quoted by Yunasril Ali, the motto that

${ }^{17}$ Lembaga Adat Propinsi Jambi, Dinamika Adat Jambi Dalam Era Global (Jambi: Lembaga Adat Propinsi, 2003), 5859.

${ }^{18}$ Nurdin Yakub, Minangkabau Tanah Pusaka (Sejarah Minangkabau) (Bukit Tinggi: Pustaka Indonesia, 1996). 
was formed from the unification of the two cultures was caused by five factors, namely: ${ }^{19}$

a) Islam was brought by traders who also served as preachers. This has an impact on the ease with which Islam spreads in the lives of the people of Kerinci.

b) Islamic teachings have an ideology that respects the culture and customs that have been embedded in society. So that there are not many obstacles in the beliefs of people who have various beliefs such as Hinduism and Buddhism.

c) Islam respects Kerinci customs as long as they do not conflict with the basic principles of Islamic teachings.

d) There are similarities in principles between Islam and the customs of the Kerinci people, such as the principles of deliberation, justice, compassion, and so on.

e) The da'wah carried out by the preachers was done gently and with full wisdom.

The development of Islam in Kerinci began to be felt at the time of Haji Abdul Latif (early 17th century AD), who was a student of Sheikh Abdur Rauf Singkil (d. 1693 AD) who spread Islamic teachings there. He adheres to the Syatariyyah Order which has the Mahzab Shafi'i of thought. He preached the method of religious studies with the nuances of Fiqh and Tarekat. His studies were also carried out with artistic activities such as with tambourines (sike), qasidah and others. In addition, he also teaches his students martial arts like Pencak. Silat, in their efforts to preach, in order to feel safe in the spread of Islam. This was done because at that time the people of Kerinci were famous for the development of occult sciences, such as skin immunity and so on. At that time, pencak silat was a mandatory provision for the people of Kerinci before going out of the area or wandering. In addition, through him, the development of Islam is also easier, namely by inviting the people of Kerinci to build a Surau as a place for gathering and preaching so that information about Islam can be easily conveyed. In fact, through his method, each Depati area has one mosque as a place to discuss shari'a law.

\section{THE TRANSFORMATION OF THE \\ ISLAMIC MOVEMENT IN KERINCI}

As previously explained, Kerinci is an area that has a relatively old civilization. The contact between Islam and cultures in Kerinci has given rise to an intense dialectic between the two, thus giving birth to new patterns and movements in society. Based on searches in various areas in Kerinci, there were new waves of Islam spreading in Kerinci. This not only creates interesting debates but also gives a new color to the people of Kerinci in viewing Islam. The movements that can be found are described as follows: The communities or organizations mentioned in the table do not at the same time explain the entire Islamic community or group in Kerinci. Some of those mentioned are classified based on movement patterns, organizational structures, organizational goals and how their development impacts on society. Important explanations related to the organization above are illustrated by the following points:

Table1. Muslim Community Data in Kerinci

\begin{tabular}{lllll}
\hline No & Community & $\begin{array}{l}\text { Organizatio } \\
\text { n Type }\end{array}$ & Leader & $\begin{array}{l}\text { Locati } \\
\text { on }\end{array}$ \\
\hline 1 & $\begin{array}{l}\text { Yuk Ngaji } \\
\text { Kerinci }\end{array}$ & $\begin{array}{l}\text { Organization } \\
\text { of Da'wah/ } \\
\text { Islamic Study }\end{array}$ & $\begin{array}{l}\text { Joni } \\
\text { Afyantori }\end{array}$ & $\begin{array}{l}\text { Koto } \\
\text { Renah }\end{array}$ \\
& & & & \\
\hline 2 & $\begin{array}{l}\text { Ikatan } \\
\text { Mahasiswa } \\
\text { Muhammadi } \\
\text { yah (IMM) }\end{array}$ & Cadre & Yoni & $\begin{array}{l}\text { Sungai } \\
\text { Penuh }\end{array}$ \\
\hline 3 & $\begin{array}{l}\text { Pemuda } \\
\text { Muhammadi } \\
\text { yah }\end{array}$ & Cadre & Risuan & Indra \\
& & & Sungai \\
& & & \\
\hline
\end{tabular}

19 Ali dkk, Adat Basendi Syara': Sebagai Fondasi Membangun Masyarakat Madani Di Kerinci, 63-64. 


\begin{tabular}{|c|c|c|c|c|}
\hline 4 & PMII Kerinci & $\begin{array}{l}\text { Cadre } \\
\text { Organization }\end{array}$ & Riki & $\begin{array}{l}\text { Sungai } \\
\text { Penuh }\end{array}$ \\
\hline 5 & GP Ansor & $\begin{array}{l}\text { Cadre } \\
\text { Organization }\end{array}$ & $\begin{array}{l}\text { Joni } \\
\text { Arman }\end{array}$ & $\begin{array}{l}\text { Sungai } \\
\text { Penuh }\end{array}$ \\
\hline 6 & $\begin{array}{l}\text { Khilafatul } \\
\text { Muslimin }\end{array}$ & $\begin{array}{l}\text { Organization } \\
\text { of Da'wah }\end{array}$ & $\begin{array}{l}\text { Abdul } \\
\text { Goni }\end{array}$ & $\begin{array}{l}\text { Kayu } \\
\text { aro }\end{array}$ \\
\hline 7 & $\begin{array}{l}\text { Lembaga } \\
\text { Dakwah } \\
\text { Islam } \\
\text { Indonesia } \\
\text { (LDII) }\end{array}$ & $\begin{array}{l}\text { Organization } \\
\text { of Da'wah }\end{array}$ & $\begin{array}{l}\text { Dwi } \\
\text { Susanto }\end{array}$ & $\begin{array}{l}\text { Kayu } \\
\text { aro }\end{array}$ \\
\hline 8 & $\begin{array}{l}\text { Jam'iyyatul } \\
\text { Islamiyah }\end{array}$ & $\begin{array}{l}\text { Organization } \\
\text { of Da'wah }\end{array}$ & $\begin{array}{l}\text { Ahmad } \\
\text { Zuhdi }\end{array}$ & $\begin{array}{l}\text { Sungai } \\
\text { Penuh }\end{array}$ \\
\hline 9 & $\begin{array}{l}\text { Himpunan } \\
\text { Mahasiswa } \\
\text { Islam (HMI) }\end{array}$ & Inauguration & $\begin{array}{l}\text { Fengki } \\
\text { Efniza }\end{array}$ & $\begin{array}{l}\text { Sungai } \\
\text { Penuh }\end{array}$ \\
\hline 10 & $\begin{array}{l}\text { Majelis Tafsir } \\
\text { al-Qur'an } \\
\text { (MTA) }\end{array}$ & $\begin{array}{l}\text { Organization } \\
\text { of Da'wah }\end{array}$ & Suhirman & $\begin{array}{l}\text { Kayu } \\
\text { Aro }\end{array}$ \\
\hline 11. & $\begin{array}{l}\text { Majelis } \\
\text { Pengajian } \\
\text { Ulama }\end{array}$ & $\begin{array}{l}\text { Da'wah } \\
\text { Community }\end{array}$ & $\begin{array}{l}\text { Martunus } \\
\text { Rahim }\end{array}$ & - \\
\hline
\end{tabular}

\section{Komunitas Yuk Ngaji (KYN) Kerinci}

This community is relatively new and is a community that often conducts recitation activities. This community office is located in Koto Renah Village, Sungai Penuh City. According to the results of research and investigation, its members are ex-HTI in the area of Sungai Penuh City and Kerinci Regency from students or young people. The membership of this group is relatively young and has a fighting spirit to defend Islam. Whereas previously the HTI organization in Kerinci had a clear structure, KYN did not have such a clear structure in membership. According to the confession of one of its members, the KYN study often includes studies on the importance of establishing a caliphate. "When I joined, sir, there was also an explanation of the importance of upholding the caliphate. Most of us also wear the niqob, the men wear beards and hisbals, sir." ${ }^{20}$ This study was previously called halaqah, but now it has changed to the term "recitation". The change in the

${ }^{20}$ Indra (Member of Komunitas Yuk Ngaji), Interview, 19 April 2021.

${ }^{21}$ Marjan Fadil, "Dimensi Kontekstual Dalam Tafsir Hizbut Tahrir Indonesia,” AL-DZIKRA 12, no. 1-20 (2018). name of the study organization group with ex-HTI membership was also found in many other areas, for example in the cities of Padang, Palembang, and Bengkulu.

$\mathrm{KYN}$ is also a manifestation of the student organization in Kerinci, Gema Liberation Kerinci. Nothing has changed from the content of this organization's study with HTI in the past, with the main idea being doctrine through da'wah, that they consider Muslims to have failed to awaken Islam because of two things, namely the weakness of fikrah Islamiyah (Islamic concept) and the absence of a correct understanding of tariqah Islamiyah. ${ }^{21}$

However, after being banned from spreading the doctrine, KYN did not openly spread the doctrine in their recitations. The appearance of this group in Kerinci itself can be seen by the way they dress, the men wear jingkang pants (above the ankles) and prohibit hisbal (lengthening the pants below the ankles), women mostly use the niqab or veil. Religious principles for this group tend to be manifested in symbols and daily behavior. Islam is also the solution to all the problems that exist on earth, so that understanding outside of Islam will be rejected, for example, philosophy and Sufism.

\section{Ikatan Mahasiswa Muhammadiyah (IMM) dan Pemuda Muhammadiyah}

Muhammadiyah is an Islamic reform movement in Indonesia that was founded in the early 20th century and is engaged in the mission of directing and guiding the people through religious education. ${ }^{22}$ This movement is consistently moving in teaching until now.

In its development, Muhammadiyah formed organizations under their auspices with the same vision, namely the Muhammadiyah Student Association (IMM) and Muhammadiyah Youth

${ }^{22}$ Aminullah Elhady, "Islamic Reform Movement In Indonesia: Role Of Muhammadiyah In Social Empowerment," International Journal of Academic Research in Business and Social Sciences 7, no. 8 (2017): 340-50. 
(PM). Both are organizations that shaded the Muhammadiyah organization which was originally brought by Ahmad Dahlan in Yogyakarta on November 18, 1912. The initial goal of the Muhammadiyah organizational movement was the purification of Islamic teachings which were heavily influenced by mystical things. In principle, this organization is based on da'wah consisting of men and women in a Sidratul Muntaha recitation. ${ }^{23}$ This da'wah activity continued until the formation of educational institutions, with the ideology of Muhammadiyah until now. IMM and PM are structurally still holding the principles brought by the central Muhammadiyah organization, but in practice, they have shifted into political organizations in the form of cadre.

The most visible difference between these two organizations is their membership. If IMM operates within the scope of students, PM is formed with young members, both students, and the general public. The activities carried out by IMM and PM have become a branch of Muhammadiyah whose targets are young people and women.

Ideologically, the Muhammadiyah organization has a strong belief that issues of religion and its rituals of worship are fundamental and standardized matters. Meanwhile, community social relations are a secondary matter and are flexible with circumstances. ${ }^{24}$ This also causes Muhammadiyah and NU organizations in Indonesia to be less strict in terms of symbols.

Muhammadiyah activities in Kerinci can be found in the main building of Muhammadiyah in Sungai Penuh City, as well as a mosque for the general public. The activities carried out by the Muhammadiyah organization are somewhat different from the activities of IMM and PM in Kerinci. Muhammadiyah focuses on regular

23 Muhammadiyah, "AD-ART Muhammadiyah," 2020.

24 Muhammad Ali, "Between Faith and Social Relations: The Muhammadiyah and Nahdlatul Ulama's recitations by studying popular commentary works and popular hadith works for Muslims, while IMM and PM are more active with the same study, but the essence of the study is about youth issues. For IMM and PM, regeneration activities are often held every year to recruit members.

\section{Khilafatul Muslimin}

Khilafatul Muslimin or KM was established in line with what is explained in the Qur'an QS Asy-Shura verse 13: "He has prescribed for you what religion $\mathrm{He}$ has commanded Noah and what We have revealed to you and what We have passed on to Abraham, Moses and Jesus, namely: Establish religion and do not be divided about it. It is very hard for the polytheists of the religion to which you call them. Allah draws to that religion whom $\mathrm{He}$ wills and guides (to Him) those who return (to Him)."

The agreement that has been formulated by Khilafatul Muslimin (KM) is illustrated by Ma'lumat for all their members on Friday, July 18, 1997 as the beginning of the founding of this organization. KM has chosen a leader or Amirul Mu'minan, namely Abdul Qadir Hasan Baraja as a representative of the international level deliberation. To date, KM's central executive office is located at the Kekhalifahan Islam Mosque in Bandar Lampung. This organization operates as an organization that accommodates Muslims in the congregation to establish a Khilafah system, which is referred to as Khilafatul Muslim led by a Kalifah, as a representative in each particular region or country. KM itself believes that they are a group based on Islam and Independence in order to prosper the entire earth, as well as to prosper humans in accordance with the teachings of Allah and the Messenger. KM also gives freedom to the teachings of other religions as a manifestation of

Fatwas and Ideas on Non-Muslims and Interreligious Relations," Journal The Muslim World 110, no. 8 (2020): 45880 . 
the congregational principles brought by them and does not allow these provisions or rules to conflict with the teachings of their respective religions. ${ }^{25}$ This means that the formulation of rules for adherents of non-Muslim religions is determined on the basis of an agreement formulated together. KM itself gets a supply of funds from its members through infaq and zakat through Baitul Maal which was founded by KM itself. KM gives rights to every human being to become their member, whether Muslim or non-Muslim without any discrimination of race, class, position and nationality. However, non-Muslims are required to make donations based on their ability to the Baitul Maal.

The provisions that have been formulated in the ma'lumat for $\mathrm{KM}$ can be described as follows; first, $\mathrm{KM}$ is based on the principles of Islam and Independence; secondly, the KM decides every case that concerns the interests of the people with the Caliphate Deliberation openly and with morality; third, $\mathrm{KM}$ seeks to realize cooperation between human beings with the principle of justice for the welfare of the universe; fourth, KM must love peace and be prohibited from showing hatred or war to any group, except for self-defense; fifth, KM and Amir and their citizens strive to build the country in all areas of life; sixth, every regional representative or Amir is willing to be elected and adheres to the principles of the Jama'ah with the preservation of the law and does not conflict with religious teachings. In addition, deliberations will later be carried out by each Amir or representatives from each region to decide on a problem that will later occur.

The Khilafatul Muslimin in Kerinci does not get free space to develop. This can be seen when an investigation is carried out in the Kayo Aro area. It is not easy to get information related to this group, because members of the KM group are actually closed and reluctant to provide information related to their group. Even recorded

\footnotetext{
${ }^{25}$ Khilafatul Muslimin, "Maklumat," n.d.
}

evidence of direct conversations with them could not be obtained. After successfully meeting one of the members and attending congregational prayers at the location of their organization, there was no difference in the pattern of worship like Muslims in general. This is because this group is not only engaged in matters of faith but also efforts to improve the system in all areas of life in the world.

The majority of KM members in Kerinci are Javanese-Kerinci residents in Kayu Aro, and some are also ex-students at the Kerinci. The ideology understood by this organization is slightly different from the HTI principles. The difference lies in the conditions for determining the leader. If HTI demands an area to be controlled, then KM hands over power only to Allah SW'T. Wherever the earth where humans stand in the territory of God. KM has not appeared in Kerinci for too long, about 3-4 years ago. ${ }^{26}$ Their activities are carried out with the principle of taqiyyah or hidden because this ideology has been banned by the current Indonesian government. As a closed community, the teachings of Islam that are delivered are still focused on one area, in the village of Telun Berasap Kayu Aro.

When performing Friday prayers at the mosque, their members generally wear clothes such as white robes wrapped in green robes, and some of them wear white turbans as head coverings.

This organization grew up in Kerinci brought from the Muko-Muko area of Bengkulu. In order to facilitate the development and smooth running of the organization's activities, they collect infaq and shadaqah funds from their members. They understand Islam as the Salafi principles that focus on the formation of the Khilafah and the Islamic behavior of the people. They have their own organizational attire which is similar to the robes for men and the hijab and veil for women but in the color of green. This clothing is used as

\footnotetext{
${ }^{26}$ Anonim (Vice Chairman of Khilafatul Muslimin), Interview, 9 April 2020.
} 
the main clothing in the implementation of activities or organizations.

\section{LDII (Lembaga Dakwah Islam Indonesia)}

The Indonesian Islamic Da'wah Institute or LDII was founded on January 3, 1972, in the city of Surabaya. At the beginning of its formation it was still known as the Islamic Employee Foundation (YAKARI) in East Java, and later changed to the name of the Islamic Employee Institute (LEMKARI) after the large deliberations (MUBES) were held in 1981. Subsequent changes were made in 1990 through the MUBES which was conducted at the direction of the Minister of Home Affairs at the time, General Rudini, who decided to change the name of the organization to the Indonesian Da'wah Institute or LDII because it had similarities with the Indonesian Karate-Do Institute.

LDII is an organization that adheres to the principle of da'wah by promoting the normative values of Nash Q.S. Ali Imran: 104, Yusuf: 108 and An-Nahal: 125. Although engaged in the principle of da'wah, LDII is also engaged in various fields of daily human life, such as education with noble character development, development of science and technology, economic development in entrepreneurship and awareness of human rights. All lines of human life that aim to elevate the dignity of people's lives are targets that LDII wants to realize, in addition to belief in Allah SWT.

Historically, LDII was an institution or organization formed by the New Order government, with the task of correcting deviations in Islamic teachings, although it later turned into a new paradigm and seemed to try to eliminate the label of Jamaat Islam which was considered heretical. ${ }^{27}$

27 Limas Dodi, "Metamorfosis Gerakan Sosial Keagamaan: Antara Polemik, Desiminasi, Ortodoksi, Dan Penerimaan Terhadap Ideologi Lembaga Dakwah Islam
As a fairly large organization in Indonesia, LDII Kerinci led by Dwi Susanto in Kayu Aro has been widely followed by the people of Kerinci. The inherent principles of this organization are also applied in its movement in the Kerinci community. LDII has a clear structure, which operates in various parts of protecting the community. There are 11 sections, namely the Membership and Organization section, the Religious Education and Training section, the Community Service section, the Youth, Arts and Sports section, the InterInstitutional Relations section, the Communication and Information Agency, the Research and Development Agency, Science and Technology, Natural Resources AND Environment, the Economics agency, human rights bodies and women's empowerment and family welfare bodies. They believe that the rules that must be followed are laws and in accordance with Pancasila, there is no doubt that LDII must submit to the legitimate government in Indonesia "we as LDII citizens must submit and obey the legitimate government, ... a simple example You just have to have an ID card, if you drive you have to have a SIM...". ${ }^{28}$

LDII that develops in society is relatively accepting of differences in belief or differences in Islam that are believed. There is no compulsion in forming the symbols of Muslims, because in their view Islam teaches ease. LDII itself does not openly state that they follow certain mahzab of thought in worship, they make it easy for Muslims to choose the easiest way of worship as long as it has a basis in Nash. Likewise with leaders who are not Muslims, LDII tends to be open as long as the leader is chosen in accordance with the rules that apply in this country. LDII also does not question the dress model, symbols and attributes worn by Moslems, because they believe that there are respective propositions that are embraced by every

Indonesia (LDII)," AL-TAHRIR: Jurnal Pemikiran Islam 17, no. 1 (2017): 227-46.

28 Edi Komarudin (Head of LDII in Autonomy Field), Interview, 6 April 2021. 
Muslim in the world. Therefore, the main reference from LDII is the Qur'an and Hadith, through $b i$ alma'na understanding and is carried out every time they conduct recitations. In Kerinci there are various levels of recitation, from kindergarten level (religion of cayenne pepper) and elementary and junior high school (pre-teen studies) to senior high school and adults.

Currently, LDII often gathers in the villages of Mekar Jaya and Jernih Jaya Kayu Aro which are subsidiaries of their organization in Kerinci. All the leaders of the sub-branches of this organization gathered at a mosque in the village to conduct recitations. This group has been in Kerinci for a very long time since NU and Muhammadiyah emerged in Kerinci Regency. In fact, according to the confession of one of their members, LDII has existed since before they were born. The studies conducted, for example, discussed the hadith works of Al-Bukhari, Muslim and so on.

\section{Jam'iyyatul Islamiyah}

JI or Jam'iyyatul Islamiyah was originally a regular recitation group conducted at a mosque in Kerinci Regency (now Sungai Penuh City), which was pioneered by Karim Jamak (1906-1996). The recitation, which is often and continues to take place at a mosque in Kerinci, has received various positive and negative responses from the community. The mosque where the study was held was later called the Jam'iyyatul Islamiyah Mosque. Some welcomed them with open arms, some did not like the teachings of Islam that he brought. This is none other than because the teachings conveyed carry a message of da'wah that leans towards understanding Sufism by interpreting the arguments of the Qur'an, with meanings that are less commonly heard by Kerinci residents. At first, this study was only followed by close relatives, but it developed into an Islamic organization called Jam'iyyatul Islamiyah.

The JI movement is often labeled as heretical by some people who are not familiar with their organization. But not a few also accept and follow the teachings brought by Karim Jamak. It can be seen by the many famous people who joined in it, such as Dr. Hamka Siregar, Prof. Dr. H. Hidayat, Prof. Dr. Imam Suprayogo, Prof. Dr. Chairil Effendy, Prof. Dr. Amin Abdullah and his wife, and many other names. This organization has also received permission from Kesbangpol in 2015 by establishing an organizational structure that includes many agencies in various regions in Indonesia and abroad, such as the DPD of West Kalimantan Province, the DPD of Sungai Penuh City, the DPD of Kerinci Regency, the Jam'iyyatul Family Association Association. Islamiyah Kuala Lumpur, Jam'iyyatul Islamiyah Siangapore Family Association and Jam'iyyatul Islamiyah Kuching Family Association in Sarawak. JI as an organization is also known for its belief in always avoiding disturbing others, offending others, and hurting others. Even this organization does not want to be involved in activities that are political and related to the material.

The main teaching brought by Karim Jamak is to shape and improve the behavior and character and morals of mankind because according to him, the true value of the realization of Islam is to shape the personality of mankind. In line with the teachings of the Prophet Muhammad, JI's teachings believe that Islam is actually manifested in the human body through the morals of personality, speech, sight, hearing, and behavior. According to a confession from one of its members, it would be wrong to mention JI as a deviant organization. Because in their opinion, JI runs according to the teachings of Nash, both from the Qur'an and Hadith. They do not mind the various teachings of Islam on this earth, because forgiveness is better able to give peace in the hearts of mankind. "iluk nyu ajaran buya tu kembali ke hati 
biar kito tenang... ${ }^{29}$ In line with this, the JI taught by Karim Jamak tries to teach the ritual of heart and mind reconstruction to get closer to Allah SWT through the Takhalli process, which is a basic effort to cleanse oneself by avoiding themselves from committing disgraceful acts, both physically and mentally; Tahalli is a process in humans as an effort to empty despicable traits and negative aspects in humans, and Tajalli means to receive the radiance of divine light into man and cultivate it within himself. Therefore, the greatest enemy of a human being is in himself. ${ }^{30}$

After Karim Jamak's death, the activities of the JI organization began to diminish, although recitations were still often held after the morning prayer and after the evening prayer. However, the existence of this organizational movement is not as massive as when this teacher figure lived. The teachings brought by him are still being taught to people who want to know their hearts so that the goals of Islam can be achieved. At the time when Karim Jamak was still alive, activities at the JI Mosque were always filled with people from outside the region, for example, from the cities of Jambi, Padang, Palembang, Lampung, Jakarta and could even come from Malaysia. This association reached its peak, especially during Eid al-Adha, where the mosque had provided a place to stay for members who came from outside the area and wanted to take part in this recitation. That's why many local people think that JI performs Hajj in their mosque, not in the Baitullah. The rituals carried out by Jam'iyyatul Islamiyah are fairly in line with the idea of Sufism which teaches how to reconstruct the human soul from negative to positive by always focusing on the formation of Akhlakul Karimah.

29 Ahmad Zuhdi (Head of DPD Jam'iyyatul Islamiyah), Interview, 2 September 2020.

\section{Majelis Tafsir Al-Qur'an (MTA)}

The Al-Qur'an Tafsir Council or MTA is a foundation that focuses on the fields of Islamic da'wah, social and education. Its central secretariat office is in Surakarta. This organization was founded by Abdullah Thufail in Surakarta on September 19, 1972, and has a license and has an official legal entity with number 23 of $1974 .{ }^{31}$ This organization was founded on the initiative of Abdullah Thufail himself. To date, MTA has had a relatively large number of members from various cities and regencies, with approximately 132 representatives from 471 branches from all over Indonesia. The main activities carried out by the MTA organization are routine recitations of the Qur'an and Sunnah which are divided into two types, namely first, recitations that are attended by people who are required to register in advance and follow the schedule of studies held by taking attendance. This type of study is carried out in all representatives of the central or branch organizations. The material provided is still related to the Qur'an and Hadith, with the lecture method and interspersed with questions and answers. The discussion of this study also develops in other sciences such as morality, fiqh, shari'ah and problems in everyday life. Second, public recitations, namely recitations that are open to the public, are attended by the general public without having to attend attendance and are carried out only in the Surakarta central building. This recitation is routinely held on Sunday mornings and is attended by many members from various regions.

MTA also forms educational foundations based on the principles of the Qur'an and Sunnah, from various levels at the center or in the regions. This education is divided into formal education and non-formal education. Until now, formal education has been formed starting from

\footnotetext{
30 Imam Suprayogo, "Jam'iyyatul Islamiyah Menjadi Perekat Persatuan Umat," n.d.

${ }^{31}$ Majelis Tafsir Al-Qur'an, "Profil MTA," n.d.
} 
Kindergarten (TK) level to High School (SMA) level. In addition, the MTA Islamic Boarding School has also been established. Non-formal education established by MTA includes TPA, PAUD and the Tahsin Education and Training Institute as well as the Tahfidz Institute. In addition, MTA is also engaged in social and humanitarian activities by donating blood, evacuating victims and so on. In Kerinci, MTA has been routinely donating blood as a form of their social activities. They have no problem with whom their blood will be distributed, including to people of other religions.

The MTA in Kerinci is a branch of the MTA in Muko-muko, Bengkulu Province and continues to North Sumatra. Currently, this organization is quite developed in Kerinci and has a branch in Sungai Tanduk Kayu Aro Village. According to one member of the MTA in Kerinci, their group is not an extremist organization. They also believe that they are a recitation group that loves peace and is very concerned about social and humanitarian issues. Islam according to MTA must be in accordance with and in line with the Qur'an, Hadith and the opinions of the Companions of the Prophet. These studies are carried out by collecting all the arguments from the Qur'an and Hadith regarding a particular theme, then deciding the most correct meaning and understanding by deliberation conducted by all members.

Islam in the view of MTA is relatively easy, just by referring directly to the Qur'an and Hadith. They accept various variations in understanding the meaning of the contents of the texts. For example, when they understand the propositions about hisbal, they do not decide on a case with only one particular argument. If there are other valid arguments as well, then it is legitimate for their group to hold those arguments "we follow the

32 Suhirman (Vice Chairman of MTA), Interview, 16 April 2021.

${ }^{33}$ Kemenag, "Pesan Kakamenag Di Pengajian MPU," n.d.
Qur'an and Sunnah if that is the law we can do"..... "our realm is to improve ourselves" .... "The MTA is not politically charged". ${ }^{32}$ Likewise in political affairs, this group does not interfere in political affairs like Muhammadiyah. In fact, if one of the group members from the MTA is involved in political affairs, they assume that person is not from their group. Because according to them politics is a matter that should not be mixed in religious matters.

\section{Majelis Pengajian Ulama (MPU)}

The Council for the Study of Ulama or MPU in Kerinci is a forum for an association of clerics, clerics, buya and ustadz in Kerinci. This study was started in 2017, and was facilitated by the Regent of Kerinci, also held at the official residence of the Regent of Kerinci. This recitation is always held every month with a focus on debriefing religious leaders in Kerinci in giving their da'wah to the community. The recitation conducted by this group has also received the blessing of the Head of the Ministry of Religion of Kerinci. ${ }^{33}$ Not much can be said about the MPU recitation community because a clear structure has not yet been established and the organization is relatively new. Currently, the chairman of MPU Kerinci is Martunus Rahim, as well as an initiator who works as a senior lecturer at an Islamic Institution in Kerinci. The study carried out is still fairly reasonable by discussing books directly in Arabic, including the Book of Figh and Tawhid as explained by the chairman of the MPU, "ngajoi kitab kunan fiqh biasunyo, tuka-tuka kitab, pukok syafi'iyyah sino i'anatut thalibin adu gu kitab taubid Mufidhul mustafid fi kitabi taubid". ${ }^{34}$

Over time, the MPU was no longer facilitated by the Regent, because there was no more budget for these activities. However, this

34 Martunus Rahim (Head of MPU), Interview, 20 October 2020. 
routine study is still carried out by moving from the mosque in various villages every month, with various themes. Because this the activity focuses on da'wah, there is not much data that can be taken from this community about their perspective on Islamic symbols. However, broadly speaking, the content of the study is delivered using traditional methods by emphasizing normative data and drawing conclusions about an understanding of a case with the collected arguments. The majority of members adhere to the Mahzab Shafi'i and accept Sufism brought by Imam Al-Ghazali.

The way this group dresses is generally wearing white clothes and for the elders in the group wearing a turban, also wearing a white cap which is traditionally worn by someone who has performed Hajj. However, there are no binding rules on how to dress, so many of the members also wear Muslim clothing in general, which is widely used by Muslim communities in Indonesia.

\section{CONCLUSION}

Islam embraced by the Kerinci Malay community is at least divided into 2 broad categories; first, the people of Kerinci are exclusive and find it difficult to accept other Islamic teachings other than Islam which they have believed in from ancient times, namely Islam with tarekat theology which does not conflict much with Kerinci customs. This group firmly adheres to the Shafi'i school in the application of everyday law. This first group is the majority of the indigenous people of Kerinci who do not mix with the outside community, nor are the immigrant communities who have lived in Kerinci for a long time. Second, the Kerinci community which is inclusive of Islamic teachings, where they are Muslim academics, the immigrant communities who have lived in Kerinci for a long time, such as the Javanese and Minang people in Kayu Aro and Sungai Penuh City, and the Kerinci community who mixes with outsiders through marriage. Both the inclusive and exclusive community groups above both give rise to a formalist/legalist Islamic way of life with their respective portions.

The understanding of formalist/legalist Islam adopted by the people of Kerinci is the easiest to develop from an inclusive society. This is evidenced by the variety of Islamic movements in locations such as in Kayu Aro with the Al-Qur'an Tafsir Council (MTA), Khilafatul Muslimin and the Indonesian Islamic Da'wah Institute (LDII) in these locations, including the Islamic community with the Salafi nuances of Yuk Ngaji Kerinci in Sungai City. Full. As a form of Islamic ideology that is displayed in everyday life, they do not impose their understanding of Islam on other people with certain symbols such as the veil or prancing pants. Although ideologically their movement, making the symbol as an ideal in religion. In addition, there are several organizational movements that use certain symbols in dressing as a manifestation of their organizational symbols, not the manifestation of Islam that they believe in, such as GP Anshor, Pemuda Muhammadiyah, LDII and Khilafatul Muslimin.

\section{BIBLIOGRAPHY}

Achmad, Ubaidillah. "Islam Formalis Versus Islam Lokalis: Studi Pribumisasi Islam Walisongo Dan Kiai Ciganjur." ADDIN 10, no. 1 (2016): 233-62.

Ahmad Zuhdi (Ketua DPD Jam'iyyatul Islamiyah). Wawancara (September 2020).

Ali dkk, Yunasril. Adat Basendi Syara': Sebagai Fondasi Membangun Masyarakat Madani Di Kerinci. Kerinci: STAIN Kernci Press, 2005.

Ali, Muhammad. "Between Faith and Social Relations: The Muhammadiyah and Nahdlatul Ulama's Fatwas and Ideas on NonMuslims and Interreligious Relations." Journal The Muslim World 110, no. 8 (2020): 458-80.

Anwar, M. Syafii. Pemikiran Dan Aksi Islam Di Indonesia. Jakarta: Paramadina, 1995.

Azra, Azyumardi. Konteks Berteologi Di Indonesia: 
Pengalaman Islam. Jakarta Selatan: Paramadina, 1999.

Bogel, Fredric V. New Formalist Criticism. New York: Palgrave Macmillan, 2013.

BPS Kabupaten Kerinci. Statistik Daerah Kabupaten Kerinci 2020. Kerinci: BPS Kabupaten Kerinci, 2020.

Dodi, Limas. "Metamorfosis Gerakan Sosial Keagamaan: Antara Polemik, Desiminasi, Ortodoksi, Dan Penerimaan Terhadap Ideologi Lembaga Dakwah Islam Indonesia (LDII)." AL-TAHRIR: Jurnal Pemikiran Islam 17, no. 1 (2017): 227-46.

Elhady, Aminullah. "Islamic Reform Movement In Indonesia: Role Of Muhammadiyah In Social Empowerment." International Journal of Academic Research in Business and Social Sciences 7, no. 8 (2017): 340-50.

Fadil, Marjan. "Dimensi Kontekstual Dalam Tafsir Hizbut Tahrir Indonesia.” AL-DZIKRA 12, no. 1-20 (2018).

Hasan, Noorhaidi. "The Salafi Movement in Indonesia: Transnational Dynamics and Local Development." Comparative Studies of South Asia, Africa and the Middle East 27 (January 2007): 83-94. https://doi.org/10.1215/1089201x-2006045.

Kemenag. "Pesan Kakamenag Di Pengajian MPU," n.d.

Khilafatul Muslimin. "Maklumat," n.d.

Lembaga Adat Propinsi Jambi. Dinamika Adat Jambi Dalam Era Global. Jambi: Lembaga Adat Propinsi, 2003.

M. Van, Bruinessen. "Introduction: Contemporary Developments in Indonesian Islam and the 'Conservative Turn' of the Early Twenty-First Century." In Contemporary Developments in Indonesian Islam: Explaining the "Conservative Turn." Singapura: Institute of Southeast Asian Studies, 2013.

Mahmuddin. "Formalisme Agama Dalam Perspektif Gerakan Sosial: Prospek Dan Tantangan Di Masa Depan." Jurnal Diskursus Islam 3, no. 1 (2015): 37-48.
Majelis Tafsir Al-Qur'an. "Profil MTA,” n.d.

Muhammadiyah. "AD-ART Muhammadiyah," 2020.

Noor, Irfan. "Sufisme Seyyed Hossein Nasr Dan Formalisme Agama Di Indonesia." ALBANJARI 13, no. 2 (2014): 143-264.

Shihab, M. Quraish. Islam Yang Saya Anut DasarDasar Ajaran Islam. Tangerang: Lentera Hati, 2018.

Suprayogo, Imam. "Jam'iyyatul Islamiyah Menjadi Perekat Persatuan Umat," n.d.

Watson, C. W. Kerinci: Two Historical Studies. Canterbury: University of Kent, 1984.

Yakub, Nurdin. Minangkabau Tanah Pusaka (Sejarah Minangkabau). Bukit Tinggi: Pustaka Indonesia, 1996.

"Mendeeling Encyclopedisch Burean Aflevering." In Note Betreffende de Afdeeling Korintii, 1915.

\section{Interviews}

Anonim (Vice Chairman of Khilafatul Muslimin), Interview, 9 April 2020.

Indra (Member of Komunitas Yuk Ngaji), Interview, 19 April 2021.

Edi Komarudin (Head of LDII in Autonomy Field), Interview, 6 April 2021.

Ahmad Zuhdi (Head of DPD Jam'iyyatul Islamiyah), Interview, 2 September 2020.

Martunus Rahim (Head of MPU), Interview, 20 October 2020.

Suhirman (Vice Chairman of MTA), Interview, 16 April 2021. 